\title{
Letter names and sounds: their implications for the phonetisation process
}

\author{
Cristina Silva • Tiago Almeida • \\ Margarida Alves Martins
}

Published online: 20 December 2008

(C) Springer Science+Business Media B.V. 2008

\begin{abstract}
Our aim was to analyse the impact of the characteristics of words used in spelling programmes and the nature of instructional guidelines on the evolution from grapho-perceptive writing to phonetic writing in preschool children. The participants were 50 5-year-old children, divided in five equivalent groups in intelligence, phonological skills and spelling. All the children knew the vowels and the consonants B, D, P, R, T, V, F, M and C, but didn't use them on spelling. Their spelling was evaluated in a pre and post-test with 36 words beginning with the consonants known. In-between they underwent a writing programme designed to lead them to use the letters $\mathrm{P}$ and $\mathrm{T}$ to represent the initial phonemes of words. The groups differed on the kind of words used on training (words whose initial syllable matches the name of the initial letter-Exp. G1 and Exp. G2-versus words whose initial syllable is similar to the sound of the initial letter-Exp. G3 and Exp. G4). They also differed on the instruction used in order to lead them to think about the relations between the initial phoneme of words and the initial consonant (instructions designed to make the children think about letter names-Exp. G1 and Exp. G3 - versus instructions designed to make the children think about letter sounds-Exp. G2 and Exp. G4). The 5th was a control group. All the children evolved to syllabic phonetisations spellings. There are no differences between groups at the number of total phonetisations but we found some differences between groups at the quality of the phonetisations.
\end{abstract}

Keywords Letters names $\cdot$ Letters sounds · Invented spelling

C. Silva $\cdot$ T. Almeida $(\varangle) \cdot$ M. Alves Martins

Instituto Superior de Psicologia Aplicada (Higher Institute of Applied Psychology-I.S.P.A.), UIPCDE, Rua Jardim do Tabaco, 34, 1149-041 Lisbon, Portugal

e-mail: talmeida@ispa.pt 


\section{Introduction}

Phonemic awareness and knowing letters are essential to understanding the alphabetic principle. The fact is that coordinating these two types of knowledge is a necessary condition if children are to understand the systematic relationships between letters and sounds (Byrne, 1998; Byrne \& Fielding-Barnsley, 1991, 1993). The research in this field has shown that phonological awareness plays a key role in the acquisition of literacy and the understanding of the alphabetic principle (Adams, 1990; Ball \& Blachman, 1991; Bryant \& Bradley, 1987), and it is now consensual that there is a reciprocal relationship between learning to read and write and the development of more complex phonemic awareness skills. Various studies have also shown that when children are trained on phonological awareness and taught the corresponding letters at the same time, this kind of training has direct effects on the success of learning to read, and that this type of intervention is more effective than ones in which phonological awareness abilities are trained on their own (Adams, Foorman, Lundbederg, \& Beeler, 1998; Byrne \& Fielding-Barnsley, 1991; Tangel \& Blachman, 1992). Nevertheless, the way in which phonological awareness and the knowledge of letters interact with one another to enhance the development of alphabetic conceptions about the written code is not yet completely clear. Quite apart from anything else, this is because in a lot of the research in this area, children are dichotomously classified as readers or non-readers without conducting additional analyses of the extent of their knowledge about written language (Ferreiro, 2002).

Knowing letters has in turn also been correlated with progress in learning to read (Adams, 1990; Alves Martins, 1996), both when children are asked to say the names of letters (Bruck, Gnesee, \& Caravolas, 1997), and when they are told to give their sounds (Caravolas, Hulme, \& Snowling, 2001). This relationship is generally explained by the fact that most letter names contain the sound in question, and this may make it easier for children to grasp grapho-phonetic relationships (Treiman, Tincoff, Rodriguez, Mouzaki, \& Francis, 1998). However, the relationships between constructs that are assessed by the name and by the sound of letters are still unclear (Levin, Shatil-Carmon, \& Asif-Rave, 2006). Probably the way in which children mobilise this knowledge is mediated by the manner in which they see the nature of writing itself (Alves Martins \& Silva, 2001).

The question of how children understand that letters represent sound components of words has recently been approached by analysing the spelling of preschool children (invented spellings or phonological spelling). The quality of this invented spelling is an indicator of children's phonological abilities, and simultaneously reveals the way in which children look at the nature of the written code and is an important predictor of their success at learning to read and write (Alves Martins, 1996; Mann, 1993). At the same time, preschool children's writing activities act as a factor in the development of more explicit forms of phonemic awareness (Adams, 1990; Alves Martins \& Silva, 2006a, 2006b; Silva \& Alves Martins, 2002, 2003; Treiman, Tincoff, \& Richmond-Welty, 1997), inasmuch as they induce metalinguistic thinking practices that have consequences for the learning of the oral segments of words. In this sense children seem to find it easier to develop alphabetic 
analytical procedures in writing activities rather than in reading ones, given that writing "may prompt children to use more systematic methods of deriving the spelling from sounds" (Bowman \& Treiman, 2002, p. 31).

Beginning with the idea that invented spelling activities involve children in an analysis of the sound structure of words and make it easier to grasp the alphabetic principle, Alves Martins and Silva (2006a) conducted various experimental studies in which they undertook intervention programs designed to make the quality of preschool children's invented spellings evolve. More precisely, they carried out three studies (op. cit.) in which they worked with children who possessed different levels of knowledge about writing - children whose spelling still showed no sign of a relationship with the oral (grapho-perceptive spelling), children whose spelling possessed an underlying term-to-term correspondence between the number of letters and syllables, but whose choice of letters was still random (syllabic spelling without phonetisation), and children whose spelling also matched the syllabic hypothesis, but who chose the right letters (syllabic spelling with phonetisation). The intervention was similar in all three experiments and was based on the following methodology: After writing a few words, the children were confronted with the spellings of a child on the level immediately above their own (e.g. syllabic/syllabic with phonetisation), and they were asked to analyse the word orally and think what letters to use, to think about the two ways of spelling the word, to choose one, and to justify their choice. In this way metalinguistic thinking was induced at the level of speech, writing, and the relationships between them. The main cognitive activities involved were: predicting the number and the type of letters to be written, comparing the child's own spelling with spellings one level higher, evaluating which one was better, and justifying the spelling.

This procedure led to a clear evolution in the quality of the children's invented spellings, and by the post-test moment many of them (particularly the ones whose initial spellings already displayed some form of correspondence with the oral) had started respecting alphabetic criteria in their writing. As other authors (Ouzoulias, 2001; Vernon, 1998) had already argued, these studies also revealed a causal link between the evolution of invented spellings and that of phonemic analysis skills, inasmuch as the children also displayed significant progresses in their phonemic awareness skills.

The various potentials for evolution in the quality of invented spellings that can be seen in this type of intervention suggest the need to deepen the effect of a number of types of linguistic variables related to both the characteristics of the words used in the programs and the nature of the teaching (particularly the capacity to induce anticipation and thinking procedures that are centred more on the sounds or the names of letters), so as to clarify what conditions best help children evolve until they understand the alphabetic principle.

Various factors of a linguistic nature concerning both the structure of the words that are to be written and the phonological structure of the letters themselves may mediate the way in which preschool children use the knowledge of letter names to learn the relationships between speech and writing. Treiman et al. (1997) showed that the probability that preschool children will correctly mobilise the first consonant when they write is greater in words whose initial syllable coincides with 
the name of a letter with which the child is familiar, such as for Portuguese language pêra (pear) or pêssego (peach), for example. It is likely that the letter " $p$ " will be mobilised more often in these examples than when children are asked to write pano (cloth) or parede (wall), where the initial phonetic sequences do not match the name of the letter "p". So when children are familiar with the names of letters, they find it easier to detect them in the pronunciation of this type of word, and this is thought to facilitate the understanding of the sound notation function that letters play within the alphabetic code. The facilitating effect that letter names possess is generally assumed to be the starting point for the evolution towards grasping the sound of the letters. The hypothesis that such an effect exists is borne up by the study by Treiman et al. (1998), who showed that learning the sound of letters is more accessible in the case of letters whose sound appears at the beginning of the letter name (as in p) than it is in that of letters where the sound comes at the end (as with s). In another study Treiman, Weatherston and Bearch (1994) found that a number of preschool children used the letter Y to spell words with the initial sound/w/(e.g. war-YR). When asked why they wrote in this way, many children said that the letter $\mathrm{Y}$ corresponded to the sound/w/. Despite this evidence, the mechanisms that make it possible to abstract the sound of the letter from its name are not yet completely clear, and there is probably an interaction with children's phonemic segmentation capabilities.

Besides the studies in English (Mann, 1993; Treiman \& Cassar, 1997), the facilitating effect of letter names has also been found in studies conducted in other languages, such as Spanish (Quintero, 1994), Hebrew (Levin, Patel, Kushnir, \& Barad, 2002), and Portuguese (Alves Martins \& Silva, 2001; Cardoso-Martins \& Batista, 2005). In the case of Portuguese the effect is more accentuated for vowels than for consonants - the opposite to the case in English (Pollo, Kessler, \& Treiman, 2005).

However, we are not aware of any studies in the literature that look at a possible facilitating effect of the sound of a letter in words whose initial syllables are close to that sound (e.g. in Portuguese, words like peru (turkey) or pesado (heavy)). This vacuum in the research is probably due to the fact that it is generally assumed that letter names are easier to learn than letter sounds (McBride-Chang, 1999; Share, 2004). The greater difficulty in learning letter sounds as opposed to letter names can be explained by the fact that in many languages letter names correspond to syllables, whereas letter sounds correspond to phonemes, which are harder to discriminate between and articulate and do not possess the acoustic form of a lexical item that is natural to a child as letters names (Treiman \& Kessler, 2003). At the same time, in children's social environments references to letters are usually based on names and not sounds, and this makes the names of letters more familiar than their sounds. Despite the issues that we have listed, some recent data (Levin et al., 2006) suggest that preschool children gain equal benefit from training letter names or training letter sounds, in terms of the impact of this knowledge on their ability to recognise words. The same authors also found that the abstraction of a letter's sound was not directly derived from the teaching of the letter's name, inasmuch as for children to familiarise themselves with the phonemic sound of a letter, they had to be taught its sound directly. 
Pre-conventional spelling activities foster a complex interaction between children's ability to segment words into their oral constituents and their ability to mobilise the right letters, which sometimes then serve as concrete supports for more precise analyses of the oral, thereby leading to a spiral process of development. A finer understanding of this reciprocal development process could perhaps be expanded by analysing the role of letter sounds and names, both at the level of the thinking processes about the oral, and at that of the facilitating characteristics of the words that are to be spelt.

It is in this context, and following on from earlier intervention programs involving invented spelling (Alves Martins \& Silva, 2006a), that we propose to assess these variables' impact on the evolution of the spelling phonetisation processes in preschool children.

We formulated the following research question:

How do the characteristics of the words used in intervention programs (words whose initial syllable matches the name of the initial letter in each word versus words whose initial syllable is similar to the sound of the initial letter in each word) and the instructions given in those programs (instructions designed to make the children think about letter names versus instructions designed to make the children think about letter sounds) affect the nature of the spelling phonetisation processes in preschool children?

\section{Methods}

The experimental design

This was an experimental study in which children were given a pre-test and a posttest intended to evaluate their invented spelling. Between the pre- and post-tests the children took part in writing programs designed to induce a restructuring of their spelling.

We created four experimental groups based on the nature of some of the words used in the intervention-facilitating words (words whose initial syllable matches the name of the initial letter versus words whose initial syllable is similar to the sound of the initial letter) - and in the instructions (instructions designed to make the children think about letter names versus instructions designed to make the children think about letter sounds) and a control group. In experimental group 1 the facilitating words used in the program contained initial syllables that matched the names of consonants with which the children were familiar, and the children were led to think about the initial letter in each word on the basis of the letter name; experimental group 2 used the same words as group 1, but the children were led to think about the initial letter in each word on the basis of the sound that corresponded to that letter; in experimental group 3 the facilitating words used in the program contained initial syllables that were close to the sounds of consonants with which the children were familiar, and the children were led to think about the initial letter in each word on the basis of the letter name; experimental group 4 used the same 
words as group 3 , but the children were led to think about the initial letter in each word on the basis of the sound that corresponded to that letter.

In short:

Experimental group 1-facilitating words whose initial syllable matched the letter name + guidelines for thought centred on the letter name.

Experimental group 2-facilitating words whose initial syllable matched the letter name + guidelines for thought centred on the letter sound.

Experimental group 3-facilitating words whose initial syllable matched the letter sound + guidelines for thought centred on the letter name.

Experimental group 4-facilitating words whose initial syllable matched the letter sound + guidelines for thought centred on the letter sound.

We also organised a set of exercises with the control group using material of the logical blocks type. The children were asked to classify geometric shapes in accordance with criteria such as identical shape, size or colour.

The experimental programs began a week after the pre-test and lasted for a fortnight. In order to be sure that any progress that might have been made was of a lasting nature, the post-test was carried out one month after the programs were concluded. The tests used at the pre and the post-test moments were the same.

\section{Participants}

The participants were 50 middle-class Portuguese children with an average age of 66.77 months and a standard deviation of 2.61 months, a minimum age of 61 months and a maximum age of 72 months. They attended various different kindergartens and had received no formal teaching about reading and writing. Their kindergarten classes did not include any regular classroom activities/instruction in relation to either phonological awareness or invented spelling.

None of the children knew how to read-a fact that was verified in an individual word reading test which had been devised for the Portuguese population (Sim-Sim \& Ramalho, 1993).

All the children who were selected presented writing based on grapho-perceptive criteria-i.e. when they wrote, they used different combinations of the letters with which they were familiar, but showed that they did not yet understand that writing symbolises the oral components of words. Consequently the choice of letters made by the children was random, and the way they wrote reflected their conceptions about the semantic properties of the referents or the graphic pictures they had of the written words, and didn't present any relation with the correct sounds of the words. Concerning the number of correct phonetisations of the pre-test words, all children were classified with zero, i.e. despite of the knowledge of some letters these children never mobilized correctly the letters known when writing. This fact was supported with the absence of reasons pointed out when they were asked about the choice of a specific letter that appeared to be correct for the dictated word.

We assessed the children's knowledge of letters. All the children who were selected knew the letters needed to write the initial sounds in the pre- and post-tests. 
Table 1 Mean scores and standard deviations of the age, the letters known, the levels of intelligence and the phonemic awareness at the pre-test

\begin{tabular}{|c|c|c|c|c|c|c|c|c|}
\hline & \multicolumn{2}{|l|}{ Age } & \multicolumn{2}{|c|}{ Letters } & \multicolumn{2}{|c|}{ Intelligence } & \multicolumn{2}{|c|}{ Phonological awareness } \\
\hline & Mean & $S D$ & Mean & $S D$ & Mean & $S D$ & Mean & $S D$ \\
\hline Exp. G1 & 6688 & 391 & 1488 & 64 & 2575 & 183 & 1850 & 193 \\
\hline Exp. G2 & 6663 & 250 & 1538 & 92 & 2538 & 200 & 1813 & 173 \\
\hline Exp. G3 & 6700 & 278 & 1513 & 99 & 2488 & 295 & 1850 & 233 \\
\hline Exp. G4 & 6688 & 223 & 1525 & 71 & 2513 & 113 & 1863 & 169 \\
\hline Control G & 6612 & 261 & 1538 & 119 & 2462 & 185 & 1912 & 125 \\
\hline
\end{tabular}

We also assessed their intelligence levels.

Given that it is a well established fact that phonemic awareness influences children's spelling ability (Caravolas et al., 2001), we also checked the level of the children's phonemic awareness.

The children were split into four experimental groups and one control group with ten members each. The groups were defined in accordance with the four experimental conditions set out above.

The five groups were equivalent in terms of age, number of letters known, level of intelligence, and phonemic awareness. Table 1 gives the means and the standard deviation for age, number of letters known, level of intelligence, and phonemic awareness.

We carried out four ANOVAs using the group as the independent variable and the children's age, number of letters known, level of intelligence, and phonemic awareness as dependent variables. The results of the ANOVAs show that there were no statistically significant differences between the groups as regards age $[F(4,45)=$ $0.13 ; p=0.975]$, number of letters known $[F(4,45)=0.42 ; p=0.791]$, level of intelligence $[F(4,45)=0.37 ; p=0.830]$, or phonemic awareness $[F(4,45)=0.31$; $p=0.867]$.

Tasks and procedure

Assessment of the children's invented spellings for the purpose of selecting the participants

In order to only select children whose invented spellings were grapho-perceptive, we individually interviewed 87 preschool children and asked them to write their name and then to spell a set of words to the best of their ability. After spelling each word they were asked to read what they had spelt. The verbal utterings that frequently accompanied the act of spelling were recorded.

We dictated five words which were organised as follows: words that are of an identical size from a linguistic point of view, but which refer to items that possess different sizes-for example: cavalo/formiga (horse/ant); words that belong to the same family and are close in linguistic terms-for example: gato/gatinho (cat/ kitten). 
This test was used as the basis for choosing 50 children whose writing was grapho-perceptive-in other words, children who did not yet establish any relationship between the spoken and written segments when they wrote, thereby clearly demonstrating that they had not understood that writing is a speech notation code. In their writing these children arranged the same letters in different ways for the different words. In doing so, in some cases they took account of the properties of the referents-e.g. by using more letters for the word cavalo (horse) than for the word formiga (ant), bearing in mind the different sizes of the two animals.

\section{Evaluating the children's knowledge of letters}

In order to determine how many and which letters the children were familiar with, they were given a set of cards bearing the letters of the alphabet in capitals ( $\mathrm{K}, \mathrm{W}$, and Y were excluded, inasmuch as they are not formally part of the Portuguese alphabet), which they were asked to name. They were then asked to write down the letters they had recognised. The range of possible points in this test was thus $0-23$. We considered that a child knew a letter when she/he correctly named it and wrote it down.

This test was also used for selection purposes, given that we only chose children who knew all the initial vowels and all the initial consonants in the words that were used in both the pre- and the post-tests.

\section{Evaluating the children's intelligence}

The level of the children's intelligence was evaluated using the coloured version of Raven's Progressive Matrices test (Raven, Raven, \& Court, 1998), because it is not very dependent on verbal aspects.

\section{Evaluating the children's phonemic skills}

In order to evaluate the children's phonemic skills we set them a battery of tests composed of three sub-tests with differing levels of difficulty (so as to address the heterogeneous nature of this particular ability). The battery included two classification tests and a segmentation test (see Appendix A).

The initial-syllable classification test was composed of 14 items preceded by two examples. In each item the children were presented with four drawings, each representing an oral word (there were no written words); two of the words in each item began with the same syllable, whereas the others started with different ones, and the children had to identify the words that began with the same one.

The initial-phoneme classification test was composed of 14 items preceded by two examples. In each item the children were presented with four drawings, each representing an oral word (there were no written words); two of the words in each item began with the same phoneme, whereas the others started with different ones, and the children had to identify the words that began with the same one.

In the phonemic segmentation test the children were asked to pronounce in isolation each of the phones in words that were presented to them in figurative form. 
Each word contained between 2 and 4 phones. The test was made up of 14 items, again preceded by two training items that modelled the division of two words into their phonemic segments.

In all the tests one point was awarded for each correct answer.

\section{Evaluating the children's invented spelling at the pre-and post-test moments}

In order to evaluate the progresses that had resulted from the spelling programs we conducted another dictation test, which served as both a pre- and a post-test instrument. In this test the children had to spell a set of words to the best of their ability. After spelling each word they were asked to read what they had spelt. The verbal utterings that frequently accompanied the act of spelling were recorded.

We dictated 36 words (bala, bico, bolo, burro, dado, dita, dono, duna, pata, pipa poço, puma, rato, rica, roda, ruga, tacho, tina, toda, tubo, vaca, vila, vota, vudu, faca, fita, foca, fumo, mata, milho, mota, mula, capa, quilo, cola, cume) (ball, beak, cake, donkey, die [as in dice], said, owner, dune, paw, barrel, well, puma, mouse, rich, wheel, wrinkle, saucepan, tub, all, tube, cow, town, vote, voodoo, knife, ribbon, seal, smoke, brush [as in undergrowth], corn, motorcycle, mule, cover, kilo, glue, peak). This list included words that began with nine different consonants (four words per consonant). All the words possessed a CVCV structure, and in those that began with the same consonant the latter was successively followed by the vowels $\mathrm{A}, \mathrm{I}, \mathrm{O}$ and $\mathrm{U}$. In most cases the pronunciation of this vowel corresponded to the name of a letter (see Appendix B).

We used a grid constructed from those developed by Ferreiro (1988) and Alves Martins (1994) to classify the invented spellings.

We used the following categories: grapho-perceptive spellings, syllabic spellings with phonetisation, and syllabic-alphabetic/alphabetic spellings.

Grapho-perceptive spellings: this category was used to classify the written output in which the children made no attempt to draw any correspondence between the oral and the written language. So children's spellings are random strings of letters that have no relationship to the sounds in the words. The spelling of the words was guided by grapho-perceptive criteria, and in their writing the children sought to take account of factors such as a minimum number of letters for each word and different combinations of letters to discriminate between different words. Generally speaking, while they were writing the children did not verbalise at all and they read written words in a global way (Fig. 1).

Syllabic with phonetisation spellings: Spellings in which the correspondence between the oral and the written language was based on syllabic units, but in which the children phonically analysed part of the spoken words in such a way as to select a pertinent letter to represent the sounds they identified. Figure 2 illustrates this type of spelling. These children also read the words syllabically.

Syllabic-alphabetic/alphabetic spellings: Spellings in which children used pertinent letters to represent all the phonemes in some of the syllables of a word, while continuing to use one letter to denote other syllables in the same word, or spellings in which the phonetic structure of the word was fully learnt and codified, 


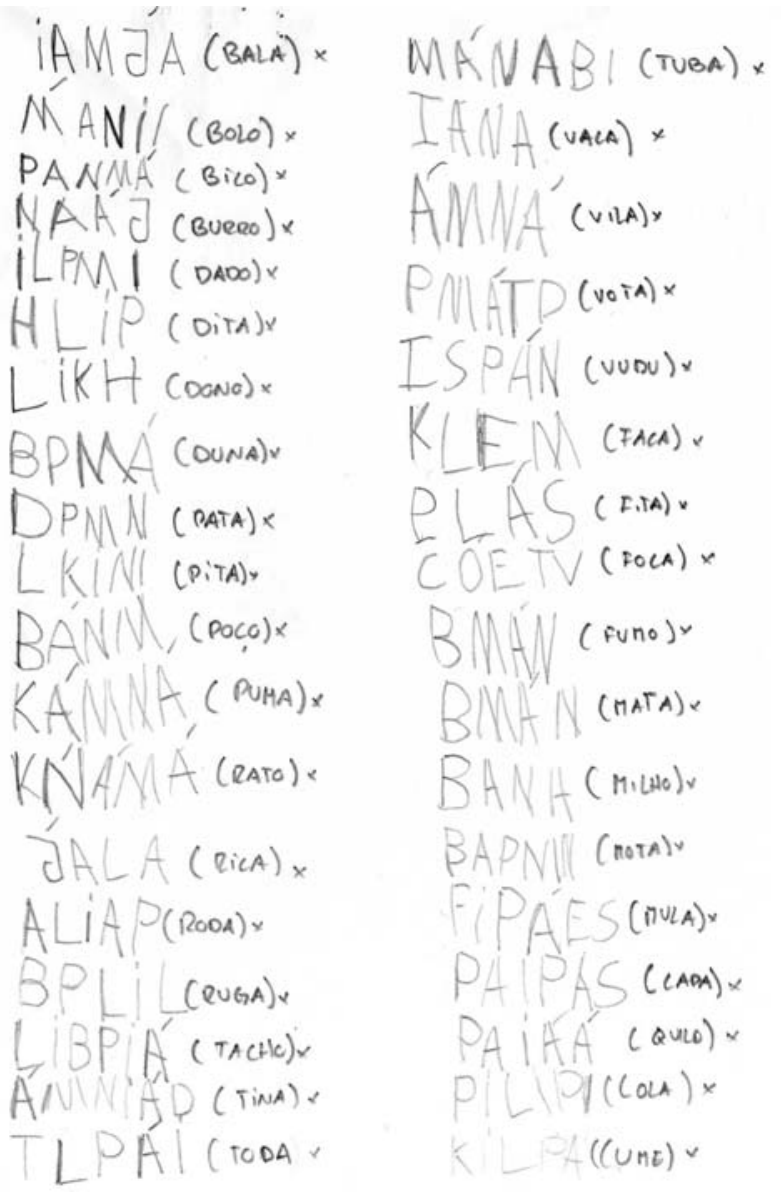

Fig. 1 Example of grapho-perceptive spelling in the pre-test phase

even though not all the applicable orthographic conventions were respected. In both cases the children used pertinent letters to represent sounds. The words were read globally. Figure 3 illustrates this type of spelling.

We classified each child in a level using the following procedure: we analysed the way she/she spelled and read each word; we then calculated the number of words that fit each type of spelling. In order to classify a child in a certain level, he/ she had to write $80 \%$ of the words (29) in accordance with the criteria defined for that level. Two independent judges, who agreed $100 \%$ of the time, made this analysis.

Besides analysing the evolution of the children's writings based on the grid, we also carried out a finer analysis of the children's phonetic spelling. We counted the total number of correct phonetisations, the number of initial consonants that were correctly phonetised, and the number of vowels that were correctly phonetised in the first syllable. 
Fig. 2 Example of invented spellings guided by syllabic criteria with phonetization

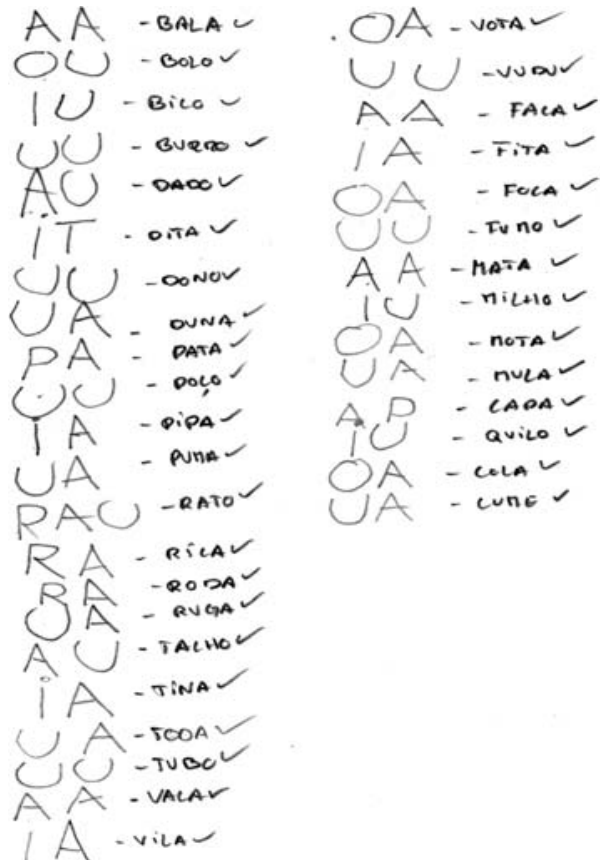

Fig. 3 Example of invented spellings guided by syllabicalphabetic/alphabetic criteria

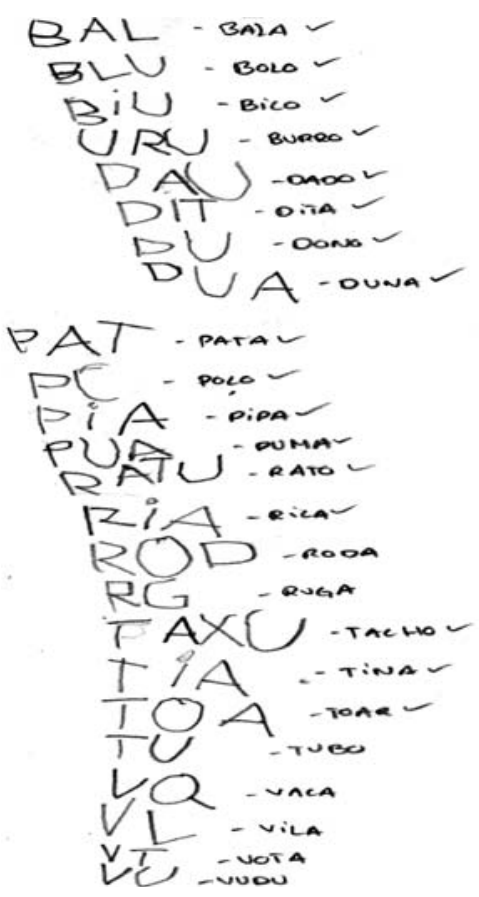




\section{Writing programs}

The writing programs lasted for five approximately 15 -min sessions each, and were designed to lead the children to use conventional letters to represent the initial consonant in words. The five sessions were implemented along 3 weeks (two sessions each week). During the intervention sessions the investigator worked individually with each child. The control group program was equivalent in time to the experimental ones, was individualized and was also conducted by the same investigator.

The words that were used in the programs were always different from those used in the pre- and post-tests. Whatever the variations that were inherent in the specificity of the experimental conditions to which each group was subjected, in every group and every session each child was asked to write a word as best he/she could, and was then shown the same word written by a hypothetical child from "another class", who used the correct letters to represent the various syllables in the word. He/she was asked to analyse both his/her spelling and that of the other "child", and to think which was the best way to spell the word and why. The child's attention was drawn to the first letter of the word. Every group used ten words in each session, and all the words in all the sessions began with the consonant $\mathrm{P}$ or $\mathrm{T}$ (sessions 1 and 2-words beginning with the consonant $\mathrm{P}$; sessions 3 and 4 -words beginning with the consonant $\mathrm{T}$; session 5-half the words began with the consonant $\mathrm{P}$ and half with the consonant $\mathrm{T}$ ).

The nature of facilitating words used at the beginning of each session and the nature of the guidelines that were given varied depending on the experimental condition allocated to each group.

In experimental groups 1 and 2 the initial syllable of the first two words in each session coincided with the name of the first letter. The initial letter of the remaining words was followed by the vowels "a", "o", "i" or "u". For example, in session 1 of the program followed by experimental groups 1 and 2 the children were asked to write the words Pena [pen $\alpha$ ] and Pêssego [pesəgu] (feather, peach), in which the initial syllable coincides with the letter name P [pe], and the words Papo [papu], Página [pajina], Povo [povu], Pousada [pozada], Pico [piku], Picada [pikada], Pulo [pulu] and Pomada [pumada] (pouch, page, people, inn, peak, sting, jump, ointment).

In experimental groups 3 and 4 the initial syllable of the first two words in each session was close to the sound of the first letter. In the remaining words the initial letter was followed by the vowels "a", "o", "i" or "u". For example, in session 1 of the program followed by experimental groups 3 and 4 the children were asked to write the words Peru [pəru] and Pesado [pəzadu] (turkey, heavy), whose initial syllable is similar to the sound represented by the letter P. The remaining words were the same as those which experimental groups 1 and 2 used in the same session.

As we said earlier, we used two versions of the guidelines when the children were asked to compare their spelling with that of the hypothetical child. The children in experimental groups 1 and 3 were asked to pay attention to the name of the first letter when they analysed the words, and were given the following instruction: "Can you tell me the name of the first letter of the word that you think is spelt best?" In 
experimental groups 2 and 4 the children were asked to pay attention to the sound of the first letter when they analysed the words, and were given the following instruction: "Can you tell me the sound of the first letter of the word that you think is spelt best?".

\section{Results}

Table 2 shows the number of children in each experimental group who had begun to use the different types of spelling by the post-test.

As we can see from Table 2, whichever experimental group they belonged to, all the children had begun to spell with phonetisation by the post-test, whereas none of them had done so in the pre-test (when all their spellings were guided by graphoperceptive criteria). On the contrary, children of the control group did not present any evolution, which indicates the success of these intervention programs for the development of more advanced invented spelling in the pre-school children. A more detailed analysis of the whole of the children's written output from experimental groups in the post-test confirms that most of them had started organising their attempts to write in accordance with syllabic criteria, in that they mobilised a conventional letter for each syllable in a word. Some children evolved to syllabicalphabetic and alphabetic spelling. There were no differences between the experimental groups. Figure 4 gives a few examples of the spellings in the preand post-tests from children of several groups.

When looking to the post-test written words, and only for the experimental groups, we verified that the letters chosen were phonetically correct for at least one of the sounds present in each syllable. This indicates the existence of more evolved conceptions of written language, reflecting the notion that the alphabetic code consists of a notation system of sounds. On the other hand children's spellings of control group remain random strings of letters that have no relationship to the sounds in the words.

Table 3 gives the means and standard deviations for the letters that were correctly phonetised in all the words, the initial consonants that were correctly phonetised, the vowels that were correctly phonetised in the initial syllable, the consonants that were correctly phonetised in the second syllable, and the vowels that were correctly phonetised in the second syllable, for the different experimental groups.

Table 2 Number of children whose writing was syllabic with phonetization and syllabicalphabetic/alphabetic at the post-test in the four experimental groups and the control group

\begin{tabular}{llll}
\hline & $\begin{array}{l}\text { Grapho- } \\
\text { perceptive }\end{array}$ & $\begin{array}{l}\text { Syllabic with } \\
\text { phonetization }\end{array}$ & $\begin{array}{l}\text { Syllabic-alphabeti/ } \\
\text { alphabetic }\end{array}$ \\
\hline Exp. G1 & 0 & 9 & 1 \\
Exp. G2 & 0 & 8 & 2 \\
Exp. G3 & 0 & 8 & 2 \\
Exp. G4 & 0 & 7 & 3 \\
Control G & 10 & 0 & 0 \\
\hline
\end{tabular}




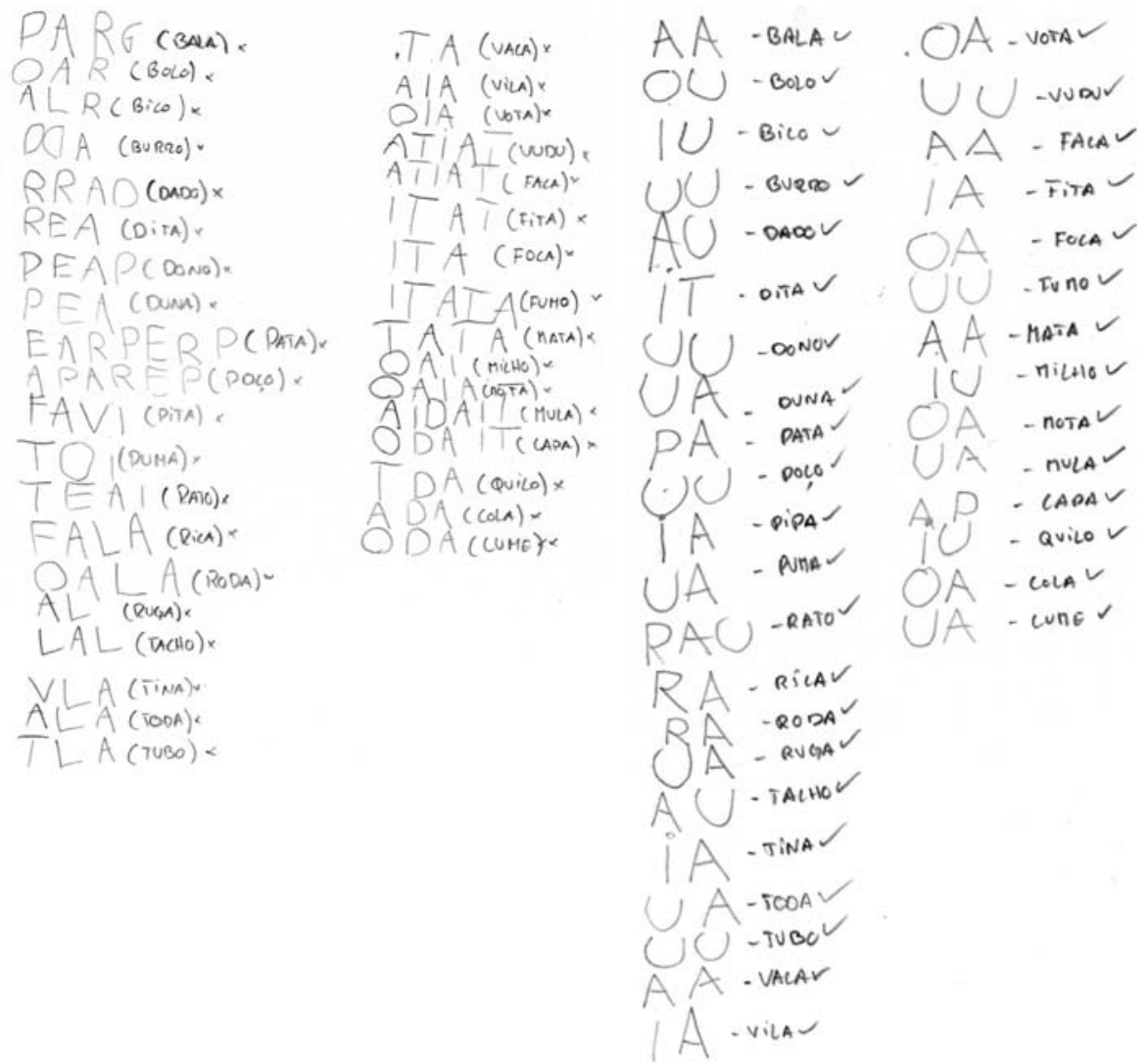

Fig. 4 Example of pre-test (left image)/post-test (right image) evolution of a participant

From this moment on, all the statistical analysis refer to the four experimental groups, because the children of the control group did not present any gain since the pre-test, continuing all the values of the variables with 0 .

We carried out five ANOVAs using the group as the independent variable and the number of letters that were correctly phonetised in all the words, the number of initial consonants that were correctly phonetised, the number of vowels that were correctly phonetised in the initial syllable as the dependent variable, the number of consonants that were correctly phonetised in the second syllable, and the number of vowels that were correctly phonetised in the second syllable, respectively. Whenever we found statistically significant differences we performed post-hoc analyses using Tukey's test.

We did not obtain any statistically significant differences for the number of letters that were correctly phonetised in all the words $[F(3,36)=1.09 ; p=0.37]$.

However, we did find statistically significant differences in terms of the number of initial consonants that were correctly phonetised $[F(3,36)=24.02 ; p=0.00]$, 
Table 3 Means and standard deviations in the post-test for the total number of correct phonetisations, the number of initial consonants correctly phonetised, the number of vowels correctly phonetised in the first syllable, and the number of consonants and vowels correctly phonetised in the second syllable, for each group

\begin{tabular}{|c|c|c|c|c|c|c|c|c|c|c|}
\hline & \multicolumn{2}{|c|}{$\begin{array}{l}\text { Total correct } \\
\text { phonetisations }\end{array}$} & \multicolumn{2}{|c|}{$\begin{array}{l}\text { Correct } \\
\text { phonetisations } \\
\text { of initial } \\
\text { consonants }\end{array}$} & \multicolumn{2}{|c|}{$\begin{array}{l}\text { Correct } \\
\text { phonetisations of } \\
\text { vowels in the first } \\
\text { syllable }\end{array}$} & \multicolumn{2}{|c|}{$\begin{array}{l}\text { Correct } \\
\text { phonetisations of } \\
\text { consonants in the } \\
\text { second syllable }\end{array}$} & \multicolumn{2}{|c|}{$\begin{array}{l}\text { Correct } \\
\text { phonetisations } \\
\text { of vowels in the } \\
\text { second syllable }\end{array}$} \\
\hline & Mean & $S D$ & Mean & $S D$ & Mean & $S D$ & Mean & $S D$ & Mean & $S D$ \\
\hline Exp. G1 & 7050 & 444 & 675 & 453 & 2713 & 514 & 225 & 341 & 3438 & 119 \\
\hline Exp. G2 & 7413 & 894 & 1588 & 499 & 1888 & 514 & 400 & 518 & 3425 & 1033 \\
\hline Exp. G3 & 7350 & 805 & 1525 & 729 & 2025 & 692 & 475 & 707 & 3312 & 360 \\
\hline Exp. G4 & 8188 & 2290 & 3225 & 727 & 375 & 727 & 2388 & 118 & 2212 & 2205 \\
\hline Control G & 0 & 0 & 0 & 0 & 0 & 0 & 0 & 0 & 0 & 0 \\
\hline
\end{tabular}

experimental group 4 achieving better results than the other three groups $(p=0.00)$, and experimental groups 2 and 3 did better ones than experimental group 1 ( $p=0.03$ and $p=0.05$, respectively).

Where the number of vowels in the first syllable that were correctly phonetised are concerned, we also obtained statistically significant differences between the groups $[F(3,36)=20.23 ; p=0.00]$, with experimental groups 1,2 and 3 doing better than experimental group $4(p=0.01)$.

Regarding the number of consonants correctly phonetised in the second syllable, the results were statistically significant $[F(3,36)=14.48 ; p=0.00]$, and the experimental group 4 achieved better results than the other three groups $(p=0.00)$.

For the number of vowels phonetised in the second syllable, we did not obtain any statistically significant differences $[F(3,36)=1.84 ; p=0.16]$, however experimental group 4 had less phonetisations.

We did a more detailed analysis to verify the differences between the experimental groups, specifically to the mobilizations of each initial consonant. Table 4 shows the results of the different experimental groups for the correct mobilization of the initial consonant. We carried out nine ANOVAs, one for each initial consonant.

Concerning letters $\mathrm{B}[F(3,36)=6.29 ; p=0.00], \mathrm{C}[F(3,36)=17.35 ; p=0.00]$, $\mathrm{D}[F(3,36)=11.37 ; p=0.00]$, and $\mathrm{M}[F(3,36)=9.39 ; p=0.00]$ the participants of the experimental group 4 achieved better results than the participants of the remaining groups $(p=0.00)$.

Considering letter $\mathrm{F}[F(3,36)=8.21 ; p=0.00]$ the participants of experimental group 4 achieved better results than the participants of experimental groups 1 $(p=0.00)$ and $3(p=0.01)$. We also verified that the experimental group 2 had better results than the experimental group $1(p=0.01)$.

There are also significant differences between the experimental groups in regard to the mobilisation of the initial $\mathrm{P}[F(3,36)=19.66 ; p=0.00]$. The participants of 


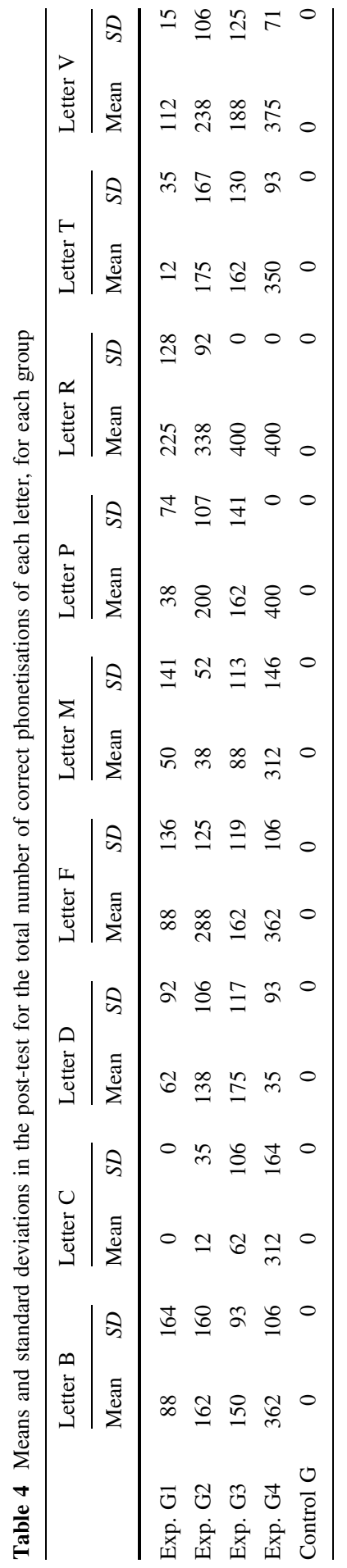


the group 4 had better results than the participants of the other groups $(p=0.00)$, and the group 2 also had better results than the group $1(p=0.01)$.

For the letter $\mathrm{R}[F(3,36)=8.79 ; p=0.00]$ the participants of experimental group 1 presented an inferior performance than the participants of the experimental groups $2(p=0.04), 3(p=0.00)$ and $4(p=0.00)$.

Regarding the letter $\mathrm{T}[F(3,36)=15.12 ; p=0.00]$ the participants of experimental group 4 achieved better results than the participants of the other three groups $(p=0.00)$, and participants of experimental groups 2 and 3 achieved better performance than the participants of experimental group 1 ( $p=0.02$ and $p=0.03$, respectively).

Finally for the letter $\mathrm{V}[F(3,36)=7.38 ; p=0.00]$ participants of experimental group 4 achieved better results than the participants of experimental groups 1 $(p=0.00)$ and $3(p=0.02)$.

With these results we verified the statistically significant differences between groups for all letters, mostly similar and consistent with previous analysis results. Also, when we proceed to an item analyses, using each word as an individual subject, the performances tendency found were confirmed. When we carried out an item analyses treating each of the 36 items of the dictated test (Appendix B) as individual subjects, ANOVAs with repeated measures using the proportions of children in each experimental group that produced the correct phonetisation of the items initial consonant, revealed similar results as those previous mentioned.

\section{Discussion}

From the point of view of the evolution of children's thinking about spelling, our results suggest that the effectiveness of the various experimental conditions was more or less the same. As it had in previous studies (Silva \& Alves Martins, 2002, 2003; Alves Martins \& Silva, 2006a, 2006b), the intervention methodology we used enabled the children to re-equate their knowledge about the nature of writing and to progress towards the understanding that writing is a way of codifying speech, and that the letters which are used should represent sounds that are identified in words. This happened even though most of the children reached this understanding in accordance with a syllabic hypothesis-which was natural since the comparison words written by the hypothetical child also conformed to syllabic criteria. Despite this, some children-also roughly the same number in each group-evolved via this task to the use of syllabic-alphabetic and alphabetic spelling criteria. This once again confirms the importance of invented spellings as a means of providing insights into the alphabetic principle (Adams, 1990; Alves Martins \& Silva, 2006a; Treiman \& Cassar, 1997).

When it came to the number of letters that were correctly mobilised in all the words, the various experimental conditions also proved to be equally effective and none of the experimental groups did better than the others.

So from this point of view, both the use of facilitating words whose initial syllable matches the letter name and the use of facilitating words whose initial 
syllable coincides with the letter sound, and also the inducement of thought processes that are guided towards the name of the first letter in the word or towards the sound of the first letter in the word, seem to lead to similar progresses in terms of the number of correct phonetisations.

However, a more detailed analysis of the differences between the various experimental groups as regards the number of initial consonants that were correctly phonetised and the number of vowels in the first syllable that were correctly phonetised, the number of consonants that were correctly phonetised in the second syllable, and the number of vowels that were correctly phonetised in the second syllable shows that the different experimental conditions appear to have different impacts on the nature of the phonetisation procedures employed. It is quite clear that in experimental group 4 the conjugation of the use of facilitating words whose initial syllable was similar to the letter sound with instructions that guided the children to think about the sounds of the first letters in the words, favoured the use of oral analysis procedures that permitted the level of abstraction needed to identify the initial phonemes in the different words and the correspondent initial consonants. This is also true when for the consonant of the second syllable. At the post-test level this effect had extended from the consonants that had been worked on $(\mathrm{P}, \mathrm{T})$ to the phonemes that correspond to other letters which were not the object of intervention (D, B, R, V, F, M, C).

On the other hand, the more widespread mobilisation of vowels to represent the sounds in the first syllable by the children in experimental group 1, which used facilitating words whose initial syllable matched the letter name along with guidelines to help the children think about the name of the first consonant in the words, suggests that as Levin et al. (2006) say, the hypothesis that the letter name would facilitate access to the letter sound is not correct. Moreover, this is the case despite the fact that all the words in the pre- and post tests began with consonants whose sound appears at the beginning of the letter name-something which Treiman et al. (1998) say makes it easier to grasp the sound in question. In fact, in Portuguese-much more than in English - the sound of vowels very often coincides with the corresponding letter name, the children in this group seem to have generalised the procedures they learnt during the program to the vowels in the initial syllables of the words they were asked to spell.

This effect wasn't verified when we analysed the differences between groups regarding the mobilization of vowels in the second syllable, since we didn't find any statistically significant differences between the groups. However, for the analysis of the effect of the different intervention programs regarding the vowel of the second syllable, we must consider the position of the vowel and the fact that they are mostly unstressed at the second syllable. Treiman, Berch, and Weatherston (1993) refer that the vowel omissions were significantly more common in unstressed syllables than in stressed syllables. On the other hand, the same authors (op. cit.) refer that the phonemes in final positions are more difficult to be noticed. Therefore the position and accentuation might contaminate, in part, the conclusions that we can take about the effects of the different intervention programs. 
The children in the intermediate experimental situations (experimental groups 2 and 3 ) phonetised the first consonant in the words significantly more than the children in experimental group 1, and significantly less than those in experimental group 4. This goes along the lines put forward by Levin et al. (2006), in that it suggests that there needs to be some form of training (or, as in this study, of facilitation) for children to grasp the phonemic sound of letters. However, this effect was not extended to the second syllable consonant, because children of these two groups were not significantly more efficient than the children of experimental group 1 . Once more, the position might have some influence. At the same time the children in experimental groups 2 and 3 were no different from the children in experimental group 1 in terms of the vowels they phonetised in the first syllable of the words, whereas on the other hand their results were better than those of the children in experimental group 4 . This once again confirms that in some way, inducing thought processes centred on letter names (by means of either the characteristics of the facilitating words or the instructions that are given) leads children to focus on vowels, at least in the case of the Portuguese language.

The analysis by items confirmed the phonetisations procedures found at the previous analysis. Children of experimental group 4 presented statistically significant higher means of correct phonetisations, considering each initial consonant when compared with children of the others groups. However, children of experimental group 2, whose experimental instruction was equally focused at the sound of the letters present superior results than children of experimental group 1 in relation to letters F, P, R and T, achieving equivalent results with experimental group 4 in relation to letter V. Children of experimental group 3, whose experimental difference in relation to experimental group 1 was the nature of the facilitation words, just presented better results than children of experimental group 1 regarding to letters $\mathrm{R}$ and $\mathrm{T}$. These analyses indicate the importance of oriented experimental guidelines inducing thought about the sound of the letters as a facilitation factor for the notation of the initial consonant.

Thus, and bearing in mind our overall set of results, it seems that we can say that, within the framework of this intervention paradigm, all the various experimental conditions facilitate the development of phonetisation procedures, and that the way in which children phonetise depends on both the nature of the facilitating words and the nature of the instructions they are given. Generally, the generic principles of the intervention with all the experimental groups present educational relevance, because they conduct to progresses at the children thought about written language and to the development of phonetisation procedures. This idea is supported by the work of Caravolas et al. (2001) that refer that the phonological spelling ability (or invented spelling) has a critical role as predictor of later reading and spelling skills.

The superiority of the results of the experimental group 4 in the phonetisations of consonants, and the respective gains, should be understand considering the nature of the difficulties that children face to understand the alphabetic logic of written language and the specific characteristics of Portuguese written language. Pollo et al. (2005) analysed the differences in phonological spelling with Brazilian and U.S. pre-school children. Their investigation indicate that the Brazilian children were three 
times more likely to start a word with vowel letter than the U.S. children, this could be explained by the different properties of the writing system to which children have been exposed. In fact the analysis of Cardoso-Martins, Resende and Rodrigues (2002) reveal that in a list of 56 frequent words present in Brazilian children's books of preschool level, 51 contained at least one vowel letter name in their pronunciation. On a similar list of 56 high frequency English words only 17 contained a letter name. So, the nature of Portuguese written language could facilitate more the mobilization of vowels, in opposition with consonants, on children's invented spelling, which make particular relevant the intervention program of experimental group 4 for the Portuguese children.

Treiman, Sotack, and Bowman (2001) suggest that children in the first stages of literacy development began to grasp print-speech relationships based in letters names. That is, the strategy letter name will serve to make preliminary links between print and speech, especially in words that contain representative phonetic sequences of the letter name. Children of experimental group 1, 2 and 3, are, some how induced (for the nature of the instruction, facilitation words or, in case of experimental group 1, by the two elements) for the utilization of this strategy, which will facilitate the comprehension that written language consists of the representation of identified sounds in words, but did not seem to induce the letters sound abstraction, for the consonants case.

One of the highest difficulties that children stand at the apprehension of the alphabetic nature of written language is that the unit of language that is presented, the phoneme, is abstract. The abstraction of initial consonants and the respective relations with the letters sounds seems to be mostly facilitated at the intervention program of experimental group 4. The highest mobilization of consonants for this group, especially at a written system whose characteristics facilitate vowels mobilizations, instead of consonants, suggest that this intervention program, at the same time that induce the comprehension of grapho-phonemic relations, might facilitate the development of initial phonemes segmentation skills. This hypothesis is supported by the conclusions of Caravolas et al. (2001), who demonstrate the existence of a reciprocal relationship between letter-sound knowledge and phoneme isolation. Also Ehri and Wilse (1980) stand that letter-sound knowledge helps pre-readers to establish a stable and concrete representations of the phonemes and promotes growth in phonemic awareness. So, in this intervention program exclusively centred at letter-sounds, that kind of knowledge is appropriate through more advanced thought procedures about the nature of written language, applying this knowledge where is necessary, i.e. during the own process of writing.

This type of research appears to be quite promising when it comes to obtaining a deeper understanding of the way in which the phonetisation procedures in invented spellings evolve towards an understanding of the alphabetic principle. It would be interesting to replicate the study and to analyse the effect that these different experimental conditions have on the mobilisation of the initial consonants in words whose first syllables include a vowel that does or does not match the applicable letter name. 


\section{Appendix A}

Battery of phonemic awareness

Initial-syllable classification test

Cards with drawings representing

Examples

bolo/nariz/navio/moinho (cake/nose/ship/windmill)

ilha/ouro/arroz/iogurte (island/gold/rice/yoghurt)

Items:

uva/asa/unha/ilha (grape/wing/nail/island)

enxada/ouriço/agulha/apito (hoe/hedgehog/needle/whistle)

rolo/sapo/figo/roupa (roll/frog/fig/clothes)

coelho/machado/piano/macaco (rabbit/axe/piano/monkey)

garrafa/galinha/pijama/moeda (bottle/chicken/pyjamas/coin)

tesoura/casaco/moinho/cavalo (scissors/coat/windmill/horse)

vaso/pipa/mesa/vaca (vase/barrel/table/cow)

chupa/fato/faca/bico (lollypop/suit/knife/beak)

janela/menina/tomate/torrada (window/girl/tomato/piece of toast)

girafa/panela/cenoura/palhaço (giraffe/pan/carrot/clown)

bota/jarro/ninho/bola (boot/jar/nest/ball)

saco/sapo/burro/mota (bag/frog/donkey/motorcycle)

laranja/medalha/lagarto/pinheiro (orange/medal/lizard/pine tree)

sino/data/dado (bell/date/die [as in dice])

Initial-phoneme classification test

Cards with drawings representing:

Examples:

colher/chave/chuva/bola (spoon/key/rain/ball)

jóia/nó/jipe/pá (jewel/knot/jeep/shovel)

Items:

alce/urso/arca/ovo (moose/bear/arch/egg)

orelha/alface/árvore/igreja (ear/lettuce/tree/church)

raposa/regador/viola/boneca (fox/watering-pot/guitar/doll)

mala/peixe/chucha/mota (bag/fish/[baby's] dummy/motorcycle)

sumo/gola/leite/gato (juice/collar/milk/cat)

buzina/cegonha/vassoura/veado (horn/stork/broom/deer)

serra/copo/cama/lupa (saw/glass/bed/magnifying glass)

fivela/telhado/janela/fogueira (buckle/roof/window/bonfire)

boca/tigre/selo/tacho (mouth/tiger/stamp/saucepan)

pato/pera/milho/chuva (duck/pear/corn/rain)

tijolo/bolacha/seringa/banana (brick/biscuit/syringe/banana) 
cebola/toalha/gaveta/cigarro (onion/towel/drawer/cigarette)

lata/luva/roda/fita (can/glove/wheel/ribbon)

desenho/camisa/dominó/novelo (drawing/shirt/domino/ball of wool)

Phonemic segmentation test

Cards with drawings representing:

Examples:

chá (tea)

osso (bone)

Items:

asa (wing)

avô (grandfather)

rua (street)

mar (sea)

gorro (cap)

via (road)

carro (car)

figo (fig)

taça (cup)

pá (shovel)

bule (teapot)

sol (sun)

lã (wool)

dia (day)

\section{Appendix B}

List of words used in the pre- and post-test dictation test

\begin{tabular}{lllllllll}
\hline B & D & P & R & T & V & F & M & C \\
\hline BALA & DADO & PATA & RATO & TACHO & VACA & FACA & MATA & CAPA \\
{$[$ bab $\alpha]$} & {$[$ dadu $]$} & {$[$ pat $\alpha]$} & {$[$ Ratu $]$} & {$[$ tafu $]$} & {$[$ vak $\alpha]$} & {$[$ fak $\alpha]$} & {$[$ mat $\alpha]$} & {$[$ kap $\alpha]$} \\
BICO & DITA & PIPA & RICA & TINA & VILA & FITA & MILHO & QUILO \\
{$[$ biku $]$} & {$[$ dit $\alpha$} & {$[$ pip $\alpha]$} & {$[$ Rik $\alpha]$} & {$[$ tin $\alpha]$} & {$[$ vil $\alpha]$} & {$[$ fit $\alpha]$} & {$[$ mi $\lambda u]$} & {$[$ kilu] } \\
BOLO & DONO & POÇO & RODA & TODA & VOTA & FOCA & MOTA & COLA \\
{$[$ bobu $]$} & {$[$ donu $]$} & {$[$ posu $]$} & {$[$ Rod $\alpha]$} & {$[$ tod $\alpha$} & {$[$ vot $\alpha]$} & {$[$ fok $\alpha]$} & {$[$ mot $\alpha]$} & {$[$ kol $\alpha]$} \\
BURRO & DUNA & PUMA & RUGA & TUBO & VUDU & FUMO & MULA & CUME \\
{$[$ buRu $]$} & {$[$ dun $\alpha]$} & {$[$ pum $\alpha]$} & {$[$ Rug $\alpha]$} & {$[$ tubu $]$} & {$[$ vvudu $]$} & {$[$ fumu $]$} & {$[$ mul $\alpha]$} & {$[$ kumə] } \\
\hline
\end{tabular}




\section{Appendix C}

List of words used in the training sessions

Experimental groups 1 and 2

\begin{tabular}{|c|c|c|c|c|}
\hline \multicolumn{5}{|l|}{ Session 1} \\
\hline Pena & Papo & Povo & Pico & Pulo \\
\hline$[$ pen $\alpha]$ & [papu] & [povu] & [piku] & [pulu] \\
\hline Pêssego & Página & Pousada & Picada & Pomada \\
\hline [pesəgu] & [pajin $\alpha]$ & {$[\operatorname{pozad} \alpha]$} & [pikad $\alpha]$ & {$[\operatorname{pumad} \alpha]$} \\
\hline \multicolumn{5}{|l|}{ Session 2} \\
\hline$\underline{\text { Peso }}$ & Parra & Podre & Pinha & Puxa \\
\hline [pezu] & [paRa] & [podrə] & [рin $\alpha]$ & {$\left[\mathrm{pu} \int \alpha\right]$} \\
\hline$\underline{\text { Pelado }}$ & Pálido & Poupado & Pimenta & Poema \\
\hline [peladu] & [palidu] & [popadu] & [pimẽt $\alpha]$ & [puem $\alpha]$ \\
\hline \multicolumn{5}{|l|}{ Session 3} \\
\hline$\underline{\text { Tema }}$ & Taça & Tolo & Tipo & Tufo \\
\hline$[\operatorname{tem} \alpha]$ & {$[\operatorname{tas} \alpha]$} & [tolu] & [tipu] & [tufu] \\
\hline Têismo & Tábua & Toutiço & Tigela & Tucano \\
\hline$\overline{\text { [teifmu] }}$ & {$[$ tabu $\alpha]$} & [totisu] & {$[$ tijel $\alpha]$} & [tukanu] \\
\hline \multicolumn{5}{|l|}{ Session 4} \\
\hline Teta & Taco & Torre & Tio & Tule \\
\hline [tet $\alpha$ ] & [taku & [toRə] & [tiu] & [tulə] \\
\hline Têbano & Tafetá & Toupeira & Tiago & Tubara \\
\hline [tebanu] & [tafəta] & [top $\alpha \mathrm{j} r \alpha]$ & [tiagu] & [tubar $\alpha]$ \\
\hline \multicolumn{5}{|l|}{ Session 5} \\
\hline Perro & Palha & Ponha & Pica & Pura \\
\hline [peRu] & {$[p a \lambda \alpha]$} & {$[$ рол $\alpha]$} & {$[\mathrm{pik \alpha}]$} & {$[$ pur $\alpha]$} \\
\hline Teso & Talho & Toda & Tia & Tuta \\
\hline [tezu] & {$[\operatorname{ta} \lambda u]$} & {$[\operatorname{tod} \alpha]$} & {$[\mathrm{ti \alpha}]$} & {$[$ tut $\alpha]$} \\
\hline Pêsame & Pátio & Pousio & Piano & Puxado \\
\hline [pezmə] & [patiu] & [poziu] & [pianu] & [pufadu] \\
\hline Têtado & Tamanca & Toucinho & Tijolo & Tulipa \\
\hline [tetadu] & [tamãk $\alpha]$ & [tosinu] & [tijolu] & [tulip $\alpha]$ \\
\hline \multicolumn{5}{|c|}{ Experimental groups 3 and 4} \\
\hline \multicolumn{5}{|l|}{ Session 1} \\
\hline Peru & Papo & Povo & Pico & Pulo \\
\hline [pəru] & [papu] & [povu] & [piku] & [pulu] \\
\hline$\underline{\text { Pesado }}$ & Página & Pousada & Picada & Pomada \\
\hline [pəzadu] & [pajin $\alpha]$ & {$[$ pozad $\alpha]$} & [pikad $\alpha]$ & {$[\operatorname{pumad} \alpha]$} \\
\hline \multicolumn{5}{|l|}{ Session 2} \\
\hline Petiz & Parra & Podre & Pinha & Puxa \\
\hline [pətif] & [paRa] & [podrə] & {$[\mathrm{pin} \alpha]$} & {$\left[\mathrm{pu} \int \alpha\right]$} \\
\hline
\end{tabular}


Appendix C continued

\begin{tabular}{|c|c|c|c|c|}
\hline \multicolumn{5}{|c|}{ Experimental groups 3 and 4} \\
\hline $\begin{array}{l}\text { Pepita } \\
\text { [pəpit } \alpha]\end{array}$ & $\begin{array}{l}\text { Pálido } \\
\text { [palidu] }\end{array}$ & $\begin{array}{l}\text { Poupado } \\
\text { [popadu] }\end{array}$ & $\begin{array}{l}\text { Pimenta } \\
\text { [pimẽt } \alpha \text { ] }\end{array}$ & $\begin{array}{l}\text { Poema } \\
\text { [puema] }\end{array}$ \\
\hline \multicolumn{5}{|c|}{ Session 3} \\
\hline Temer & Taça & Tolo & Tipo & Tufo \\
\hline [temər] & {$[\operatorname{tas} \alpha]$} & [tolu] & [tipu] & [tufu] \\
\hline Telhado & Tábua & Toutiço & Tigela & Tucano \\
\hline [te $\lambda$ adu] & {$[$ tabu $\alpha]$} & [totisu] & {$[$ tijel $\alpha]$} & [tukanu] \\
\hline \multicolumn{5}{|l|}{ Session 4} \\
\hline$\underline{\text { Temor }}$ & Taco & Torre & Tio & Tule \\
\hline [temor] & [taku] & [toRə] & [tiu] & [tulə] \\
\hline Tecido & Tafetá & Toupeira & Tiago & Tubara \\
\hline [tesidu] & [tafəta] & [topajr $\alpha]$ & [tiagu] & [tubar $\alpha]$ \\
\hline \multicolumn{5}{|c|}{ Session 5} \\
\hline Pedir & Palha & Ponha & Pica & Pura \\
\hline [pədir] & {$[p a \lambda \alpha]$} & {$[\operatorname{pon} \alpha]$} & {$[\mathrm{pik} \alpha]$} & [pur $\alpha]$ \\
\hline$\underline{\text { Tenaz }}$ & Talho & Toda & Tia & Tuta \\
\hline [tenaf] & {$[\operatorname{ta} \lambda u]$} & {$[\operatorname{tod} \alpha]$} & {$[\mathrm{ti \alpha}]$} & {$[$ tut $\alpha]$} \\
\hline Pepino & Pátio & Pousio & Piano & Puxado \\
\hline [pəpinu] & [patiu] & [poziu] & [pianu] & [pufadu] \\
\hline Tesoura & Tamanca & Toucinho & Tijolo & Tulipa \\
\hline [tezor $\alpha$ ] & {$[\operatorname{tam} \tilde{a} \mathrm{k} \alpha]$} & [tosinu] & [tijolu] & [tulip $\alpha]$ \\
\hline
\end{tabular}

\section{References}

Adams, M. (1990). Beginning to read: Thinking and learning about print. Cambridge, MA: MIT Press.

Adams, M., Foorman, B., Lundberg, I., \& Beeler, T. (1998). Phonemic awareness in young children: A classroom curriculum. Baltimore: Brookes.

Alves Martins, M. (1994). Conceptualizações infantis sobre a linguagem escrita (Early conceptualization about written language). Discursos, 8, 53-70.

Alves Martins, M. (1996). Pré-história da aprendizagem da leitura. Lisboa, Portugal: ISPA.

Alves Martins, M., \& Silva, C. (2001). Letter names, phonological awareness and the phonetization of writing. European Journal of Psychology of Education, 16, 605-617.

Alves Martins, M., \& Silva, C. (2006a). The impact of invented spelling on phonemic awareness. Learning and Instruction, 16, 41-56.

Alves Martins, M., \& Silva, C. (2006b). Phonological abilities and writing among portuguese preschool children. European Journal of Psychology of Education, 21, 163-182.

Ball, E., \& Blachman, B. A. (1991). Does phoneme awareness training in kindergaten make a difference in early word recognition and developmental spelling? Reading Research Quarterly, 24, 49-66.

Bowman, M., \& Treiman, R. (2002). Relating print and speech: The effects of letter names and word position on reading and spelling performance. Journal of Experimental Child Psychology, 82, 305-340.

Bruck, M., Gnesee, F., \& Caravolas, M. (1997). A cross-linguistic study of early literacy acquisition. In B. Blachman (Ed.), Foundations of reading acquisition and dyslexia: Implications for early interventions (pp. 145-162). Mahwah, NJ: Lawrence Erlbaum.

Bryant, P., \& Bradley, L. (1987). Problemas de leitura na criança (Children reading problems). Porto Alegre, Brazil: Artes Médicas. 
Byrne, B. (1998). The foundations of literacy. Hove, UK: Psychology Press.

Byrne, B., \& Fielding-Barnsley, R. (1991). Evaluation of a program to teach phonemic awareness to young children. Journal of Educational Psychology, 83, 451-455.

Byrne, B., \& Fielding-Barnsley, R. (1993). Evaluation of a program to teach phonemic awareness to young children: A 1 year follow-up. Journal of Educational Psychology, 85, 104-111.

Caravolas, M., Hulme, C., \& Snowling, M. (2001). The foundations of spelling ability: Evidence from a 3 year longitudinal study. Journal of Memory and Language, 45, 751-774.

Cardoso-Martins, C., \& Batista, A. (2005). O conhecimento do nome das letras e o desenvolvimento da escrita: Evidência de crianças falantes do português (Letter-names knowledge and the development of writing: Evidence from Portuguese-speaking children). Psicologia, Reflexão e Critica, 18, 330-336.

Cardoso-Martins, C., Resende, S. M., \& Rodrigues, L. A. (2002). Letter name knowledge and the ability to learn to read by processing letter-phoneme relations in words: Evidence form Brazilian Portuguese-speaking children. Reading and Writing, 15, 409-432.

Ehri, L. C., \& Wilse, L. S. (1980). The influence of orthography on reader's conceptualization of the phonemic structure of words. Applied Psycholinguists, 1, 371-385.

Ferreiro, E. (1988). L'écriture avant la la lettre. In H. Sinclair (Ed.), La prodution des notations chez le jeune enfant (pp. 18-69). Paris: Presses Universitaires de France.

Ferreiro, E. (2002). Escritura y oralidad: Unidades, niveles de análisis y consciencia metalinguistica (Writing and speech: Units, levels of analyses and metalinguistic awareness). In E. Ferreiro (Ed.), Relaciones de (in)dependencia entr oralidad y escritura. Barcelona: Geddisa editorial.

Levin, I., Patel, S., Kushnir, T., \& Barad, N. (2002). Letter names: Effect on letter saying on spelling and word recognition in Hebrew. Applied Psycholinguistic, 23, 269-300.

Levin, I., Shatil-Carmon, S., \& Asif-Rave, O. (2006). Learning of letter names and sounds and their contribution to word recognition. Journal of Child Psychology, 93, 139-165.

Mann, V. (1993). Phoneme awareness and future reading ability. Journal of Learning Disabilities, 26, 259-269.

Mcbride-Chang, C. (1999). The ABCs of the ABCs: The development of letter name and letter sound knowledge. Merril-Palmer Quarterly, 45, 285-309.

Ouzoulias, A. (2001). L'emergence de la conscience phonémique: apprentissage sensoriel ou développment conceptuel. In G. Chauveau (Ed.), Comprendre l'enfant lecteur (pp. 101-127). Paris: Retz.

Pollo, T. C., Kessler, B., \& Treiman, R. (2005). Vowels, syllables and letters names: Differences of young children's spelling in English and Portuguese. Journal of Experimental Child Psychology, 92, $161-181$.

Quintero, G. (1994). El uso y función de las letras en el período pre-alfabético (Function and utilization of letters on the pre-syllabic period). Lectura y Vida, 15, 28-38.

Raven, J., Raven, J. C., \& Court, J. H. (1998). Manual for Raven's progressive matrices and vocabulary scale. Section I. General overview. Oxford, UK: Oxford Psychologists Press.

Share, D. (2004). Knowing letters name and learning letters sound: A causal connection. Journal of Child Psychology, 88, 213-233.

Silva, C., \& Alves-Martins, M. (2002). Phonological skills and writing of pre-syllabic children. Reading Research Quarterly, 37, 466-483.

Silva, C., \& Alves Martins, M. (2003). Relations between children's invented spelling and the development of phonological awareness. Educational Psychology, 23, 3-16.

Sim-Sim, I., \& Ramalho, G. (1993). Como lêem as nossas crianças. Caracterização do nível de literacia da população escolar portuguesa (How Portuguese children read. Characterization of the literacy level of Portuguese school population). Lisboa, Portugal: Ministério da Educação, Gabinete de Estudos e Planeamento.

Tangel, D. M., \& Blachman, B. A. (1992). Effect of phoneme awareness instruction on kindergarten invented spelling. Journal of Reading Behaviour, 24, 233-262.

Treiman, R., Berch, D., \& Weatherson, S. (1993). Children's use of phoneme-grapheme correspondence in spelling: Roles of position and stress. Journal of Educational Psychology, 85, 466-477.

Treiman, R., \& Cassar, M. (1997). Spelling acquisition in English. In C. A. Perfetti, L. Rieben, \& M. Fayol (Eds.), Learning to spell: Research, theory, and practice across languages (pp. 61-80). Hillsdale, NJ: Erlbaum. 
Treiman, R., \& Kessler, B. (2003). The role of letter names in the acquisition of literacy. In R. Kail (Ed.), Advances in child development and behaviour (Vol. 31, pp. 105-135). San Diego, CA: Academic Press.

Treiman, R., Sotack, L., \& Bowman, M. (2001). The roles of letters names and letters sounds in connecting print and speech. Memory \& Cognition, 29, 860-873.

Treiman, R., Tincoff, R., \& Richmond-Welty, E. (1997). Beyond zebra: Prescoolers knowledge about letters. Applied Psycholinguistic, 18, 391-409.

Treiman, R., Tincoff, R., Rodriguez, K., Mouzaki, A., \& Francis, D. (1998). The foundations of literacy: Learning the sounds of the letters. Child Development, 69, 1524-1540.

Treiman, R., Weatherson, S., \& Bearch, D. (1994). The role of letters name in children's learning phoneme-grapheme relations. Applied Psycholinguistic, 15, 97-122.

Vernon, S. (1998). Escritura y consciencia fonológica en niños hispano-parlantes (Writing and phonological awareness on Spanish-speaking children). Infancia Y Aprendizaje, 81, 105-120. 